\title{
Long-term changes in the snow-firn pack stratigraphy on Ürümqi glacier No. 1, eastern Tien Shan, China
}

\author{
WANG Feiteng, ${ }^{1}$ LI Zhongqin, ${ }^{1}$ R. EDWARDS, ${ }^{2}$ LI Huilin ${ }^{1}$ \\ ${ }^{1}$ Key Laboratory of Cryosphere and Environment/Tien Shan Glaciological Station, Cold and Arid Regions Environmental and \\ Engineering Research Institute, Chinese Academy of Sciences, Lanzhou 730000, China \\ E-mail: wangfeiteng@Izb.ac.cn \\ ${ }^{2}$ Desert Research Institute, 2215 Raggio Parkway, Reno, NV 89512-1095, USA
}

\begin{abstract}
We report on changes to the snowpack of Ürümqi glacier No. 1, eastern Tien Shan, China, resulting from climate change between 1961 and 2005. Data from more than 120 snow pits were used to investigate temporal changes in the snow stratigraphy for three periods 1961-62, 1980-83 and 2002-05. Both the thickness and structure of the snow were found to be significantly altered by climatic warming. The proportion of coarse-grained firn, which is usually formed by infiltration water, was found to have increased from $40 \%$ to $65 \%$ over the period $1961-2005$, and the distribution of the glacier zones also changed significantly, with all boundaries moving up-slope. The recrystallizationinfiltration zone disappeared in 1989. The mean ablation rate over the melt season increased by $\sim 26 \%$ from 1962 to 1980 at the west branch site and by $75 \%$ from 1980 to 2004 at the east branch site.
\end{abstract}

\section{INTRODUCTION}

The snow-firn pack is the interface between the atmosphere and the underlying ice and controls the exchange of energy and mass (Brun and others, 1989, 1992). Albedo and, hence, ablation are controlled by snow surface characteristics, principally grain size (Grenfell and others, 1994; Marshall and Oglesby, 1994; Fily and others, 1998), and the densification of the snow controls trapping of air in the firn and ice (Alley and Bentley, 1988; Arnaud and others, 1998).

Global warming over recent decades has resulted in shrinkage and changes in characteristics of most of the world's alpine glaciers (Dyurgerov and Meier, 2000). Snowpack stratigraphy and the distribution of the different zones of the glacier are basic features which are sensitive to climate change (Shumskii, 1964; Paterson, 1994).

Over the past 45 years, Ürümqi glacier No. 1 (UG1) in northwest China has shrunk by $11 \%$, and the characteristics of its snowpack have changed. Previous studies on this glacier have focused on runoff, mass balance, terminus location and thickness ( $\mathrm{Li}$ and others, 2003; Yang and others, 2005; Ye and others, 2005; Han and others, 2006; Jing and others, 2006) but did not investigate long-term changes in the stratigraphy or changes in the spatial distribution of the different zones. In July 2002 a multi-year field campaign was instigated to investigate seasonal changes in the characteristics of the glacier's snowpack and compare them against historical data. The research was performed as part of the Program for Glacier Processes Investigation (PGPI) carried out by the Tien Shan Glaciological Station (TGS), Chinese Academy of Sciences, since July 2002.

\section{SITE DESCRIPTION, DATASETS AND OBSERVATIONS}

UG1 $\left(43^{\circ} 05^{\prime} \mathrm{N}, 86^{\circ} 49^{\prime} \mathrm{E}\right)$, located at the headwaters of the Ürümqi river, in the eastern Tien Shan, northwest China, is a small valley glacier with two branches, east and west. The two branches became separated into two independent glaciers in 1993 as the glacier terminus receded up the valley. In 2001 the total area of the glacier was approximately $1.84 \mathrm{~km}^{2}$. The east branch of the glacier is currently $2.23 \mathrm{~km}$ long, with a maximum elevation of $4250 \mathrm{~m}$, while the narrower west branch is approximately $2.54 \mathrm{~km}$ long, with a maximum elevation of $4484 \mathrm{~m}$.

Local meteorological data have been recorded from 1958 to 2005 at the Daxigou meteorological station located at 3539 ma.s.l., $3 \mathrm{~km}$ downstream from the glacier terminus. During the period 1996-2005, the mean annual temperature and precipitation were $-5.1^{\circ} \mathrm{C}$ and $450.6 \mathrm{~mm}$, respectively. Typically, $90 \%$ of the precipitation in this region occurs between May and September. Between 1959 and 2005, the glacier's equilibrium-line altitude (ELA) was located at an average of $4055 \mathrm{~m}$ a.s.l.

Stratigraphic observations of the snowpack have been conducted above the ELA on both branches at elevations of $4068-4150 \mathrm{~m}$ (where the ice surface slope is about $2-6^{\circ}$ ) since 1961. The observations were made according to the International Classification for Seasonal Snow on the Ground (Colbeck and others, 1990) and included snowpack depth, density, ice and dust layers, grain size and type and temperature. Continuous datasets from more than 120 snow-firn pits were obtained for three periods: 196162, 1980-83 and 2002-05 (Table 1).

\section{RESULTS AND DISCUSSION}

\section{Snowpack stratigraphy}

The snow stratigraphy of an alpine glacier reflects processes of snow metamorphism and melt at specific locations on the glacier (Shumskii, 1964). Alteration of these characteristics over long time periods can be a direct result of climate change.

Three typical snow stratigraphy profiles of the east branch of UG1 at altitudes of 4068-4150 m are shown in Figure 1. Common stratigraphic layers included fresh snow, finegrained firn, medium-grained firn, coarse-grained firn, dust layers, ice layers and superimposed ice.

To quantify the variations in the snow-firn pack composition, 120 snow-firn stratigraphic profiles were selected. 


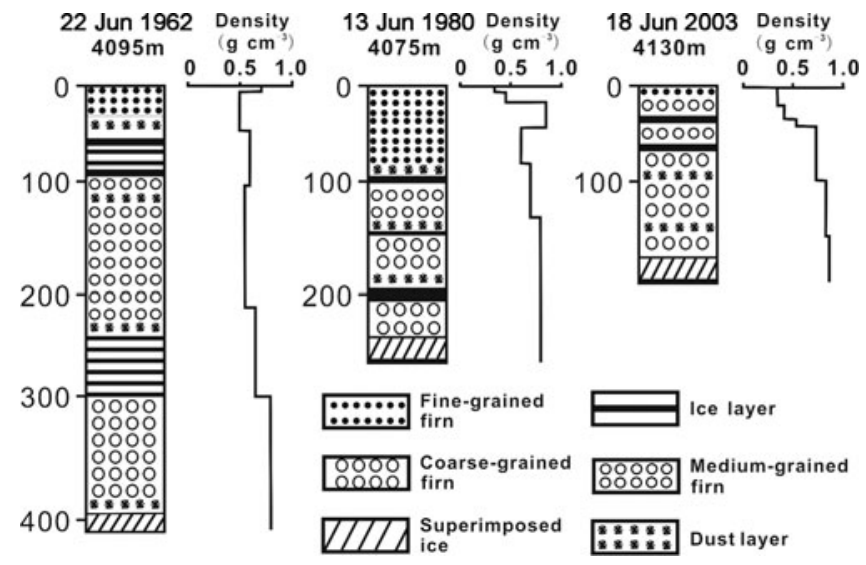

Fig. 1. Typical stratigraphic profiles of eastern branch snow-firn pack for the different time periods.

They included 26 profiles from the period 1961-62, 34 profiles from 1981-83 and 60 profiles from 2002-05.

Figure 2 shows the average stratigraphic composition of the snow-firn packs. In the period 1961-62 the proportion of coarse-grained, medium-grained and fine-grained firn, fresh snow and other layers (e.g. ice layers, dust layers, depth hoar) accounted for $40 \%, 25 \%, 22 \%, 6 \%$ and $7 \%$ of the snowpack respectively. In 1981-83, the proportion of the coarse-grained firn layer and medium-grained firn layer increased to $55 \%$ and $22 \%$, while the proportion of finegrained firn decreased from $25 \%$ to $12 \%$. By $2002-05$ the coarse-grained firn layer had increased to $65 \%$ and the proportion of fine-grained firn had continued to decrease, from $12 \%$ to $7 \%$ between the 1980 s and the 2000 s.

To summarize, from 1961 to 2005, stratigraphic profiles of the snow-firn pack became less complex, ice layers and ice lenses almost or completely disappeared and coarsegrained firn became the dominant firn type (increasing from $40 \%$ to $65 \%$ ). All of these changes in the snow-firn pack correspond to a warming trend in regional climate, which became more pronounced between 1985 and 2005. The changes in the composition of the snowpack also reflect changes in the distribution of the glacier zones.

\section{Changes in the number of annual layers, percolation and density}

Dust and ice layers occur in specific seasons (e.g. spring and summer). This seasonality permits identification of annual layers and hence can be used to date the snow layers. At

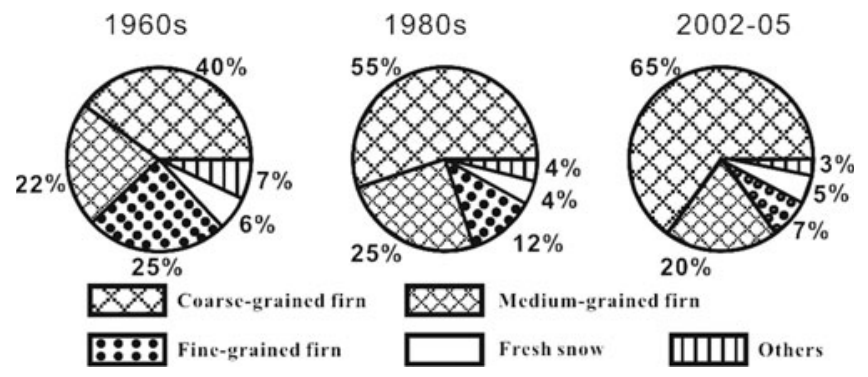

Fig. 2. Stratigraphic composition of snow profiles for the different time periods.

UG1, Wang and others (2006) found that one dust layer is preserved in the snow-firn pack per year, as the result of two dust layers merging because of percolation during the summer. Annual layers were thus identified and measured based on single dust layers. Ice layers in the snowpack indicate the presence of small amounts of liquid water. Observations showed that ice layers usually form in spring and summer. In spring, the daytime surface temperature exceeds $0^{\circ} \mathrm{C}$, leading to a partial melting of the snow, and the water refreezes at night, forming an ice layer. In summer, ice layers form when meltwater penetrates downward and refreezes above an impermeable layer such as a layer of glacier ice, or even coarse firn.

Long-term changes in stratigraphy from the three time periods were investigated using historical data collected in 1961-62 and 1980-83 and new data collected in 2002-05. In general, the data suggest that the time required to transform snow into ice has decreased, and the volume of water percolating in the snowpack and the bulk density have increased substantially. For example, between 1961 and 1962 an average of 5.2 dust layers were found in the west branch snowpack (Table 1), suggesting that 5 years of snow accumulation was present above the ice. However, during 1980-83 and 2002-05 the average number of dust layers above the ice (and hence the number of annual layers) was 4.6 and 2.5 respectively. During the same time periods, the average number of dust layers on the east branch decreased from 4.5 to 3.3. The declining number of annual layers identified by the dust suggests that the time required to transform the snow-firn pack into ice has been steadily decreasing.

As well as the decrease in the number of dust layers in the snowpack over the three periods, a decrease was also observed in the number of ice layers. In 1961-62, the west

Table 1. Data series for snow-firn pack on UG1

\begin{tabular}{|c|c|c|c|c|c|c|c|}
\hline \multirow[t]{2}{*}{ Period } & \multirow[t]{2}{*}{ Site } & \multirow[t]{2}{*}{$\begin{array}{l}\text { Number } \\
\text { of pits }\end{array}$} & \multirow{2}{*}{$\begin{array}{l}\text { Altitude } \\
\text { ma.s.l. }\end{array}$} & \multirow{2}{*}{$\begin{array}{l}\text { Mean snow } \\
\text { depth } \\
\text { cm w.e. }\end{array}$} & \multirow[t]{2}{*}{$\begin{array}{l}\text { Avg. number } \\
\text { of ice layers }\end{array}$} & \multirow[t]{2}{*}{$\begin{array}{l}\text { Avg. number } \\
\text { of dust layers }\end{array}$} & \multirow{2}{*}{$\begin{array}{c}\text { Avg. density } \\
\mathrm{kg} \mathrm{m}^{-3}\end{array}$} \\
\hline & & & & & & & \\
\hline \multirow[t]{2}{*}{$1961-62^{*}$} & West branch & 20 & 4100 & 133.2 & 7 & 5.2 & 0.54 \\
\hline & East branch & 6 & 4095 & 144.0 & 9.0 & 4.5 & 0.53 \\
\hline \multirow[t]{2}{*}{$1980-83^{*}$} & West branch & 28 & 4068 & 102.0 & 3.6 & 4.6 & 0.58 \\
\hline & East branch & 6 & 4075 & 128.4 & 3.0 & 3.8 & 0.60 \\
\hline \multirow[t]{2}{*}{$2002-05^{\dagger}$} & West branch & 6 & 4150 & 72.0 & 2.0 & 2.5 & 0.65 \\
\hline & East branch & 54 & 4130 & 92.4 & 2.9 & 3.3 & 0.68 \\
\hline
\end{tabular}

Sources: ${ }^{*}$ LIGC (1984); ${ }^{\dagger}$ this study. 
Table 2. Long- term stratigraphic observation sites on UG1

\begin{tabular}{lccc}
\hline Site & Date & $\begin{array}{c}\text { Elevation } \\
\text { ma.s.l. }\end{array}$ & ELA \\
& & ma.s.l. \\
\hline West branch & 1962 & 4100 & 4075 \\
East branch & 1980 & 4068 & 4038 \\
& 1980 & 4075 & 4038 \\
& 2004 & 4130 & 4074 \\
\hline
\end{tabular}

branch contained 7 ice layers, but this decreased to 3.6 and 2 in 1980-83 and 2002-05 respectively. On the east branch, the number of ice layers decreased from 9 to 2.9 over the same period. The decrease in ice layers can be explained by an increase in the percolation of meltwater which destroys the ice layers.

Corresponding to these changes, the average bulk density of the snow-firn pack increased by $20.4 \%$ on the west branch and $28.3 \%$ on the east branch between 1961-62 and 2001-05.

\section{Snowpack ablation}

Four long-term stratigraphic observation sites above the ELA were selected to investigate the snowpack response to climate change during spring and summer (Table 2). Snowfirn stratigraphy was recorded every 10 days between May and September in 1962 and 1980 on the west branch and 1980 and 2004 on the east branch.

Snow depth and mean ablation rates for the different time periods are shown in Table 3. The mean ablation rate over the melt season increased at the west branch site by $\sim 26 \%$ from 1962 to 1980 and by $75 \%$ from 1980 to 2004 at the east branch site.

The slopes of the linear regression lines in Figure 3 reflect the mean ablation rate of the snowpack during the melt season. We observe that ablation at the west branch site increased between 1962 and 1980, with the regression slope increasing from 0.3 to 0.51 . From 1980 to 2004 at the east branch site, ablation can be divided into two periods: 1 May-4 July (days 1-65) (period 1), and 5 July-31 August (days 66-123) (period 2). For period 1, the ablation is remarkably similar from 1980 to 2004, but during period 2 the ablation rate increased significantly, the regression slope increasing from 0.27 to 1.25 .

Differences in the absorption of solar radiation, determined by slope, surface albedo, aspect and shading, affect glacier ablation rates (Van de Wal and others, 1992). In the period for which there are data for both branches (1980), the slope of the regression line, and hence the ablation rate, is
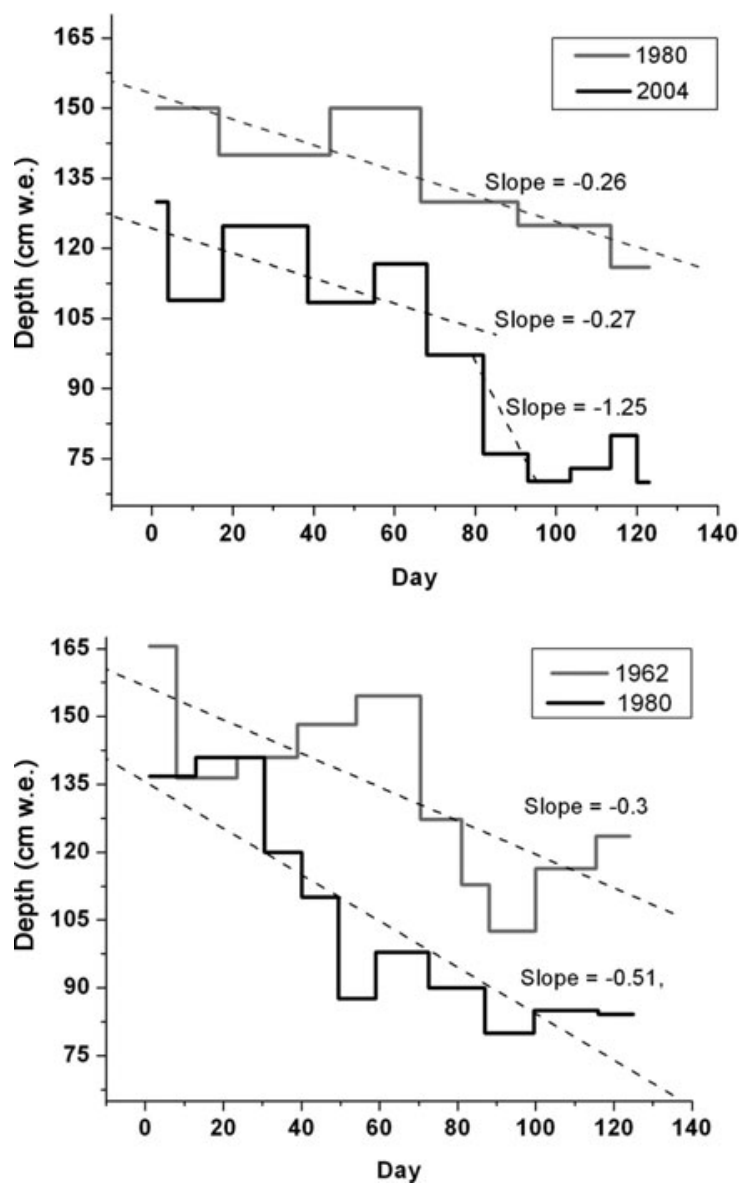

Fig. 3. The temporal development of the snow-firn pack during the melt season (1 May-31 August (days 1-123)) at different times.

higher for the west branch than for the east branch. The difference is explained by the lower surface slope and shading of the west branch compared to the east branch.

\section{Spatial changes in the glacier zones}

The distribution of the glacier's zones has changed over the past 45 years. Xie and Huang (1965) found that in 1962 the glacier consisted of four zones from terminus to summit: an ablation zone, an infiltration-congelation zone, an infiltration zone and a recrystallization-infiltration zone (zone classification according to Shumskii, 1964). By 1989, the recrystallization-infiltration zone had disappeared, being taken over by the infiltration zone. Meanwhile, the boundaries of all zones moved upward and the accumulation area shrank considerably. By 2004, in addition to the continued change and upward march of the zone boundaries, a small meltwater pool (approximately $30 \mathrm{~m}^{2}$ ) emerged at the upper

Table 3. Changes in snow depth and ablation rate, 1962-2004

\begin{tabular}{|c|c|c|c|c|c|c|}
\hline Site & Date & $\begin{array}{l}\text { Mean snow-firn depth } \\
\text { cm w.e. }\end{array}$ & $\begin{array}{l}1 \text { May depth } \\
\text { cm w.e. }\end{array}$ & $\begin{array}{l}31 \text { Aug. depth } \\
\text { cm w.e. }\end{array}$ & $\begin{array}{l}\text { Ablation loss } \\
\text { cm w.e. }\end{array}$ & $\begin{array}{l}\text { Mean melt-season ablation rate } \\
\qquad \text { cm w.e. } \mathrm{d}^{-1}\end{array}$ \\
\hline West branch & 1962 & 132.8 & 165.6 & 123.6 & 42.0 & 0.34 \\
\hline West branch & 1980 & 103.2 & 136.7 & 84.1 & 52.6 & 0.43 \\
\hline East branch & 1980 & 135.2 & 150.0 & 116.0 & 34.0 & 0.28 \\
\hline East branch & 2004 & 95.9 & 130.0 & 70.0 & 60 & 0.49 \\
\hline
\end{tabular}


end of the east branch (4224 m a.s.I.), evidently as a result of air-temperature rise and absorption of solar radiation from increasingly exposed rocks ( $\mathrm{Li}, 2005)$. The appearance of the meltwater pool suggests the melting of UG1 is ongoing at both ends.

\section{Climate change and snow-firn stratigraphy response}

Data from the Daxigou meteorological station (3539 m a.s.I.) show that the local annual mean temperature increased by about $0.8^{\circ} \mathrm{C}(95 \%$ significance level) between 1959 and 2005. Temperature change was particularly strong after 1997. For example, the summer (June-August) mean temperature ranged from 3.0 to $4.6^{\circ} \mathrm{C}$ during 1958-96, and from 4.4 to $5.8^{\circ} \mathrm{C}$ after 1997 , indicating a step increase of $1.0^{\circ} \mathrm{C}$ (Table 3 ). There was also a strong increase in the annual precipitation rate observed at Daxigou meteorological station. Measurements show an increase of approximately $85 \mathrm{~mm}\left(1.9 \mathrm{~mm} \mathrm{a}^{-1}\right)$ or $20.8 \%$ over the past 45 years (Li and others, 2006). Ye and others (2005) suggest that one impact of warming (enhanced ablation) tends to overcome the effect of enhanced accumulation through precipitation increase on glacier mass/runoff changes over the last 45 years. We observe that the temperature increase is the main reason for the changes to the snow-firn stratigraphy and the ablation rate on UG1 during the period 1961-2005.

\section{CONCLUSION}

Long-term data were used to determine temporal changes of characteristics of the snow-firn stratigraphy and ablation on UG1.

During the last 45 years, features of snowpack stratigraphy, including depth, structure and composition, were found to be significantly altered by climate warming. In the stratigraphy, the proportion of coarse-grained firn, which is usually formed by infiltration water, was found to have increased from $40 \%$ to $65 \%$ during the period 1961-2005. The recrystallization-infiltration zone observed in the $1960 \mathrm{~s}$ turned into an infiltration zone in the 1980s, and a small meltwater pool has emerged at the upper end of the east branch in the 2000s, indicating melting occurring at both ends of the glacier. The mean ablation rate over the melt season increased by $\sim 26 \%$ from 1962 to 1980 at the west branch site and by $\sim 75 \%$ from 1980 to 2004 at the east branch site.

\section{ACKNOWLEDGEMENTS}

This research was supported by the Knowledge Innovation Project of the Chinese Academy of Sciences (CAS; grants KZCX2-YW-127) and the National Natural Science Foundation of China (grants 40631001, 40571033, 40371028 and J0630966). Support for this research has been provided under the Program for Glacier Processes Investigation (PGPI) conducted by the Tien Shan Glaciological Station, CAS.

\section{REFERENCES}

Alley, R.B. and C.R. Bentley. 1988. Ice-core analysis on the Siple Coast of West Antarctica. Ann. Glaciol., 11, 1-7.

Arnaud, L., V. Lipenkov, J.M. Barnola, M. Gay and P. Duval. 1998. Modelling of the densification of polar firn: characterization of the snow-firn transition. Ann. Glaciol., 26, 39-44.
Brun, E., E. Martin, V. Simon, C. Gendre and C. Coléou. 1989. An energy and mass model of snow cover suitable for operational avalanche forecasting. J. Glaciol., 35(121), 333-342.

Brun, E., P. David, M. Sudul and G. Brunot. 1992. A numerical model to simulate snow-cover stratigraphy for operational avalanche forecasting. J. Glaciol., 38(128), 13-22.

Colbeck, S.C. and 7 others. 1990. The international classification for seasonal snow on the ground. Wallingford, Oxon., International Association of Hydrological Sciences. International Commission on Snow and Ice.

Dyurgerov, M.B. and M.F. Meier. 2000. Twentieth century climate change: evidence from small glaciers. Proc. Natl. Acad. Sci. USA (PNAS), 97(4), 1406-1411.

Fily, M., C. Leroux, J. Lenoble and C. Sergent. 1998. Terrestrial snow studies from remote sensing in the Solar spectrum and the thermal infrared. In Schmitt, B., C.D. Bergh and M. Festou, eds. Solar system ices. Dordrecht, etc., Kluwer Academic Publishers, 421-441.

Grenfell, T.C., S.G. Warren and P.C. Mullen. 1994. Reflection of solar radiation by the Antarctic snow surface at ultraviolet, visible, and near-infrared wavelengths. J. Geophys. Res., 99(D9), $18,669-18,684$

Han, T., Y. Ding, B. Ye, S. Liu and K. Jiao. 2006. Mass-balance characteristics of Ürümqi glacier No. 1, Tien Shan, China. Ann. Glaciol., 43, 323-328.

Jing, Z., K. Jiao, T. Yao, N. Wang and Z. Li. 2006. Mass balance and recession of Ürümqi glacier No. 1, Tien Shan, China, over the last 45 years. Ann. Glaciol., 43, 214-217.

Lanzhou Institute of Glaciology and Cryopedology (LIGC). 1984. Annual reports of Tianshan glaciological station. Vol. 2. Lanzhou, Chinese Academy of Sciences. [In Chinese.] Li, Z. 2005. A glacier melt water pool was discovered at summit of the east branch of the Glacier No. 1 at Ürümqi River head, Tianshan Mts., Xinjiang. J. Glaciol. Geocryol., 27(1), 150-152. [In Chinese.]

Li, Z., T. Han, Z. Jing, H. Yang and K. Jiao. 2003. A summary of 40year observed variation facts of climate and Glacier No. 1 at headwater of Ürümqi River, Tianshan, China. J. Glaciol. Geocryol., 25(2), 117-123. [In Chinese.]

$\mathrm{Li}, \mathrm{Z}$. and 9 others. 2006. Seasonal variability of ionic concentrations in surface snow and elution processes in snow-firn packs at the PGPI site on Ürümqi glacier No. 1, eastern Tien Chan, China. Ann. Glaciol., 43, 250-256.

Marshall, S. and R.J. Oglesby. 1994. An improved snow hydrology for GCMs. Part 1: Snow cover fraction, albedo, grain size, and age. Climate Dyn., 10(1-2), 21-37.

Paterson, W.S.B. 1994. The physics of glaciers. Third edition. Oxford, etc., Elsevier.

Shumskii, P.A. 1964. Principles of structural glaciology. New York, Dover Publications.

Van de Wal, R.S.W., J. Oerlemans and J.C. van der Hage. 1992. A study of ablation variations on the tongue of Hintereisferner, Austrian Alps. J. Glaciol., 38(130), 319-324.

Wang, F., Z. Li, X. You and C. Li. 2006. Snow to ice evolution process observation and study at percolation zone on Glacier No.1 at Ürümqi river head. J. Glaciol. Geocryol., 28(1), 45-53. [In Chinese.]

Xie, Z. and M. Huang. 1965. An evolution of the snow-snow grains layer and ice formation in the Glacier No. 1 at the headwaters of the Ürümqi River, Tianshan. In Y. Shi, ed. Studies of glaciology and hydrology on the Ürümqi River, Tianshan. Beijing, Science Press. Academia Sinica. Lanzhou Institute of Glaciology and Geocryology, 1-14. [In Chinese.]

Yang, H., Z. Li, B. Ye, K. Jiao and Z. Zhao. 2005. Study on mass balance and process of Glacier No. 1 at the headwaters of the Ürümqi River in the past 44 years. Arid Land Geogr., 28(1), 76-80. [In Chinese with English summary.]

Ye, B. and 6 others. 2005. The Urumqi River source Glacier No. 1 , Tianshan, China: changes over the past 45 years. Geophys. Res. Lett., 32(21), L21504. (10.1029/2005GL024178.) 